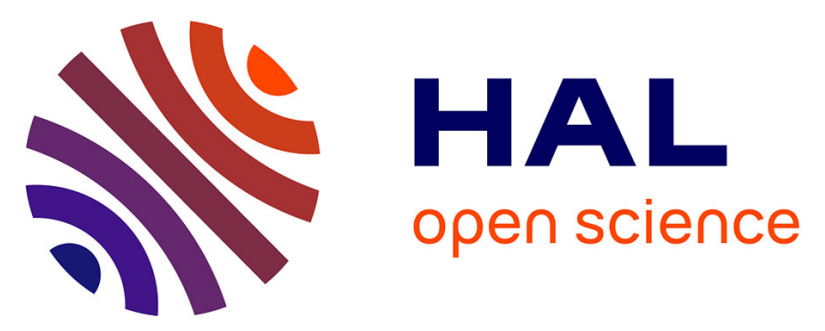

\title{
Date of death of domestic caprines assessed by oxygen isotopic analysis of developing molars: Implications for deciphering the calendar of pastoral activities in prehistory
}

Nicolas Lazzerini, Antoine Zazzo, Aurélie Coulon, Tsagaan Turbat, Charlotte Marchina, Sébastien Lepetz

\section{To cite this version:}

Nicolas Lazzerini, Antoine Zazzo, Aurélie Coulon, Tsagaan Turbat, Charlotte Marchina, et al.. Date of death of domestic caprines assessed by oxygen isotopic analysis of developing molars: Implications for deciphering the calendar of pastoral activities in prehistory. Journal of Archaeological Science, 2020, 120, pp.105163. 10.1016/j.jas.2020.105163 . mnhn-02934319

\section{HAL Id: mnhn-02934319}

\section{https://hal-mnhn.archives-ouvertes.fr/mnhn-02934319}

Submitted on 9 Sep 2020

HAL is a multi-disciplinary open access archive for the deposit and dissemination of scientific research documents, whether they are published or not. The documents may come from teaching and research institutions in France or abroad, or from public or private research centers.
L'archive ouverte pluridisciplinaire HAL, est destinée au dépôt et à la diffusion de documents scientifiques de niveau recherche, publiés ou non, émanant des établissements d'enseignement et de recherche français ou étrangers, des laboratoires publics ou privés. 


\title{
Date of death of domestic caprines assessed by oxygen isotopic analysis of developing molars: Implications for deciphering the calendar of pastoral activities in prehistory
}

\author{
Nicolas Lazzerini ${ }^{\mathrm{a}, *}$, Antoine Zazzo ${ }^{\mathrm{a}}$, Aurélie Coulon ${ }^{\mathrm{b}, \mathrm{c}}$, Tsagaan Turbat ${ }^{\mathrm{d}}$, Charlotte Marchina ${ }^{\mathrm{e}}$, \\ Sébastien Lepetz ${ }^{\mathrm{a}}$ \\ a Archéozoologie, Archéobotanique: Sociétés, Pratiques et Environnements (AASPE), Muséum National d'histoire Naturelle, CNRS, CP 56, 55 Rue Buffon, 75005, Paris, \\ France \\ ${ }^{\mathrm{b}}$ Centre d'Ecologie et des Sciences de la Conservation (CESCO), Muséum National d'histoire Naturelle, CNRS, Sorbonne Université, CP 135, 57 Rue Cuvier, 75005, \\ Paris, France \\ ${ }^{c}$ Centre d'Ecologie Fonctionnelle et Evolutive (CEFE), CNRS, Université Paul Valéry Montpellier 3, EPHE, IRD, 34090, Montpellier, France \\ ${ }^{\mathrm{d}}$ Institute of Archaeology, Mongolian Academy of Sciences, Mongolia \\ ${ }^{\mathrm{e}}$ Institut Français de Recherche sur l'Asie de l'Est (IFRAE), Inalco, Université de Paris, CNRS, 2 Rue de Lille, 75007, Paris, France
}

\section{A R T I C L E I N F O}

\section{Keywords:}

Sequential $\delta^{18} \mathrm{O}$ analyses

Modelling

Mongolia

Egiin Gol

Seasonality of birth

Funerary practices

Xiongnu

\begin{abstract}
A B S T R A C T
The assessment of the date of death (DOD) of animals found in archaeological sites provides insights into the exploitation of their environment by ancient mobile and sedentary populations. In an attempt to overcome the limitations of the traditional methods, we determine the DOD of domestic caprines using sequential oxygen isotope analysis of developing tooth enamel. We built a reference set composed of developing molars from 14 modern sheep and goats from Western and Central Mongolia with known DOD. The teeth were sequentially sampled, and $\delta^{18} \mathrm{O}$ sequences were modelled using a cosine function in order to position the lowermost $\delta^{18} \mathrm{O}$ value $\left(\delta_{\mathrm{f}}\right)$ within the annual cycle. We found that $\delta_{\mathrm{f}}$ values are strongly linearly correlated with the DOD $\left(R^{2}=0.88\right)$, allowing the use of this regression to estimate the DOD with a precision of about $\pm 25 \mathrm{~d}(1 \sigma)$. This method was applied to determine the DOD of caprines found in two graves in the Xiongnu necropolis of Egiin Gol, Mongolia. We determined a slaughter date of late July and late September for the two graves, respectively, suggesting that burial occurred during the warm season. By combining this information with age at death assessed using tooth eruption stages and tooth wear patterns, we were also able to determine that caprine birth occurred mostly in April and was strongly controlled within this seasonal window by the herders, much like in Mongolia today.
\end{abstract}

\section{Introduction}

The timing of slaughter of domestic or wild animals is a key parameter to understand interactions between humans and their environment in the past. Indeed, the moment when an animal is slaughtered relates to husbandry, hunting and settlement strategies, i.e. when and why the archaeological sites were used by humans (e.g. Carter, 2001; Helmer et al., 2005; Hesse, 1982; Lubinski, 2001; Nývltová Fišáková, 2013). Animals also play a role in various ritual practices, and in this context, seasonality of slaughter can also suggest the existence of a sacrificial calendar (e.g. Crubézy et al., 1996; Henton et al., 2014; Lepetz and Decanter, 2013).
Three different approaches have been developed thus far to determine the date of death (DOD) of animals found in archaeological sites. All of these approaches are based on the analysis of teeth, the most resistant and often the best preserved skeletal remains in archaeological contexts (Kohn and Cerling, 2002; Newesely, 1989; Smith and Tafforeau, 2008; Trautz, 1967). The first approach is based on the analysis of known sequences of tooth eruption (e.g. Hoppe et al., 2004; Noddle, 1974; Silver, 1963) and tooth wear (e.g. Ervynck, 2005; Grant, 1982; Greenfield and Arnold, 2008; Payne, 1973; Zeder, 2006). This method, which requires prior knowledge of the timing of tooth growth, can provide a precise estimate of the animal's age at death (Greenfield and Arnold, 2008) but the accuracy cannot be less than 2 months and

\footnotetext{
* Corresponding author.

E-mail addresses: nilazzerin@gmail.com, nicolas.lazzerini@edu.mnhn.fr (N. Lazzerini), antoine.zazzo@mnhn.fr (A. Zazzo), sebastien.lepetz@mnhn.fr (S. Lepetz).
} 
decreases with the age of the animal (Jones, 2006). However, this method only indirectly informs on the date of slaughter, as it requires an a priori estimate of the date of birth (e.g. Lepetz and Decanter, 2013; Rodríguez-Hidalgo et al., 2016). The second approach is based on cementochronology, i.e. the interpretation of the cyclic patterns of growth of tooth cement, characterised by the alternation of distinct broad/translucent (summer) and narrow/opaque (winter) layers (i.e. Burke and Castanet, 1995; Crubézy et al., 1996; Gourichon and Parmigiani, 2016; Greenfield et al., 2015; Landon, 2014; Li et al., 2017; Pike-Tay, 1995). The length of the last cement layer relative to the maximum expected length enables determination of the time of year when the animal died. The precision of cementochronology varies depending on the time of year, from 1 to 3 months during winter up to 6 months during summer (Burke and Castanet, 1995; Nývltová Fišáková, 2013; Schmaus et al., 2019). But most of the time, the estimate of the date of death remains qualitative, i.e. allowing researchers to distinguish between cold and warm seasons (i.e. Burke and Castanet, 1995; Greenfield et al., 2015; Li et al., 2017; Schmaus et al., 2019). Moreover, the precision of this approach relies not only on the good preservation of the cement, but also on the absence of apatite crystallites that can introduce bias in the determination of the date of death (Stutz, 2002). Inter- and intra-individual variability in cementogenesis can also hamper the determination of the date of death (Burke and Castanet, 1995). Other factors, such as age (Naji et al., 2016) and geographical variability (Grue and Jensen, 1976), can also bias the results. The third approach is based on tooth microwear analysis, i.e. the analysis of the microscopic features produced by food on the occlusal surface of teeth. Due to a high turnover rate, dental microwear reflects the diet of the last days or weeks of an animal's life ("the last super effect") (Grine, 1986; Henton et al., 2017; Mainland et al., 2016; Mainland, 1998; Rivals et al., 2015; Rivals and Deniaux, 2005; Rodríguez-Hidalgo et al., 2016; Solounias and Semprebon, 2002). Tooth microwear can hence potentially record the season of death, assuming that seasonally available food resources can be distinguished by specific microwear signals (Henton et al., 2017). This method, which requires large assemblages ( $N$ individuals $>10$ ), has been used to distinguish between single and multiple mortality events in fossil assemblages (Rivals et al., 2015, 2009; Rodríguez-Hidalgo et al., 2016). The temporal precision of this method has not been assessed in detail. It depends on several parameters, including knowledge of the seasonality of plant growth and the types of plants consumed, as well as the fact that the observer records the marks subjectively (Teaford, 2007). This rapid review of the available methods illustrates their current limits in terms of temporal precision. There is therefore a need to develop a method which is precise and does not depend on a priori assumptions (i.e. period of birth, dietary inputs).

Stable isotope analysis of serial tooth enamel samples is a suitable alternative to investigate the season of death of mammals with highcrowned teeth. This method relies on the fact that in terrestrial mammals, the stable oxygen isotope ratios $\left(\delta^{18} \mathrm{O}\right)$ of tooth enamel bioapatite are linked to the $\delta^{18} \mathrm{O}$ of drinking water and plant water ingested (Kohn, 1996; Longinelli, 1984; Luz and Kolodny, 1985; Pederzani and Britton, 2019). $\delta^{18} \mathrm{O}$ in precipitation and plant water reflect local temperature at high and middle latitudes, with higher $\delta^{18} \mathrm{O}$ values in summer and lower $\delta^{18} \mathrm{O}$ values in winter (Dansgaard, 1964; Fricke and O'Neil, 1999; Rozanski et al., 1993). Seasonal variations in $\delta^{18} \mathrm{O}$ values of environmental water are then recorded in the $\delta^{18} \mathrm{O}$ of enamel bioapatite during tooth growth (Bernard et al., 2009; Fricke and O'Neil, 1996; Koch et al., 1989; van Dam and Reichart, 2009). Thus, sequential sampling of bioapatite allows the reconstruction of detailed records of seasonal variations in diet and climate during the time period of tooth formation. This method has been used on ever-growing teeth, in this case tusks, to determine the season of death of proboscideans (El Adli et al., 2017; Fisher et al., 2003; Fisher and Fox, 2007; Koch et al., 1989; Stuart-Williams and Schwarcz, 1997). In order to extend it to ungulate teeth with definite growth periods, the method requires selecting young animals, for which the mineralisation process was still on-going at the time of their death. We are aware of only two studies where $\delta^{18} \mathrm{O}$ analysis of immature ungulate teeth has been performed in order to determine the nature (catastrophic or attritional) of archaeological assemblages (Julien, 2009; Julien et al., 2015; Knipper et al., 2008). However, quantitative determination of the date of death was not possible because it requires a reference set with animals whose DOD is known with precision. This is because tooth mineralisation takes several months to complete, and as a result of this process, the isotopic signal of fully mineralised enamel is shifted and dampened compared with the input (environmental) signal (Passey and Cerling, 2002; Balasse, 2003, 2002; Zazzo et al., 2005). Although the impact of the mineralisation process on the isotopic value should be smaller on developing tooth enamel than on mature enamel, this remains to be tested and quantified.

Our aim is to establish a proof-of-concept for DOD determination using $\delta^{18} \mathrm{O}$ analysis of developing ungulate teeth. To this end, we built a reference set composed of developing molars from modern caprines from Western and Central Mongolia with known DOD. We then applied the method to the caprine material from the archaeological site of Egiin Gol (Xiongnu culture, 4th c. BCE-2nd c. CE), in order to illustrate the potential of our approach to document the calendar of pastoral activities of ancient communities in Mongolia.

\section{Materials}

\subsection{Modern reference set}

The modern reference set comes from two different locations in Mongolia. The first location is situated in the district (sum) of Nogoonnuur, north of the province (aimag) of Bayan-Ölgii, in the most western part of the country, and the second location is situated $40 \mathrm{~km}$ north of the city of Tsetserleg, in the district of Ikhtamir, in the centre of the Arkhangai province (Fig. 1). These two regions are characterised by a strong continental climate with long, cold winters and short, hot summers. Average annual rainfall is $131 \mathrm{~mm}$ and $303 \mathrm{~mm}$ for the Nogoonnuur and Ikhtamir districts, respectively, with maximum of precipitation occurring during summer (http://fr.climate.org). Due to the strong continental climate, the seasons are defined as follows: spring (April and May), summer (June-August), autumn (September and October), and winter (November-March), following Mohammat et al. (2013) and Piao et al. (2006).

We sampled developing molars from 14 modern domestic sheep (Ovis aries, $n=9$ ) and goats (Capra hircus, $n=5$ ) in their second or third year (Table 1). Because animals had different ages at death we selected the second molar from two sheep and the third molar from seven sheep and five goats. The animals were sourced from different families of nomadic pastoralists with different mobility patterns in terms of distance, frequency of movement and grazing surface accessed by the herds. Information about pastoral practices was documented through interviews conducted yearly with the herders. Season of birth ranges from January to May, with a main lambing period between March and April. Because livestock are grazing on pasture and drinking water from local streams and plant water, their teeth should be a good recorder of seasonal variations in $\delta^{18} \mathrm{O}$ values of environmental water. Study animals were slaughtered on five different occasions: July $2013(n=2)$, June $2015(n=2)$, September $2016(n=4)$, November $2017(n=4)$ and late June-July $2018(n=2)$ (Table 1$)$. The mandibles were collected immediately after slaughter and were defleshed and cleaned by boiling. Then, developing teeth were extracted from the mandibular bone with a cut-off wheel.

\subsection{Archaeological samples}

Mongolia was occupied by populations whose funeral practices, lifestyles, agro-pastoral activities and economic circuits are the subject of much research (e.g. Honeychurch, 2010; Kovalev and Erdenebaatar, 2009; Kradin, 2011; Taylor, 2017; Wright and Makarewicz, 2015; Zazzo 


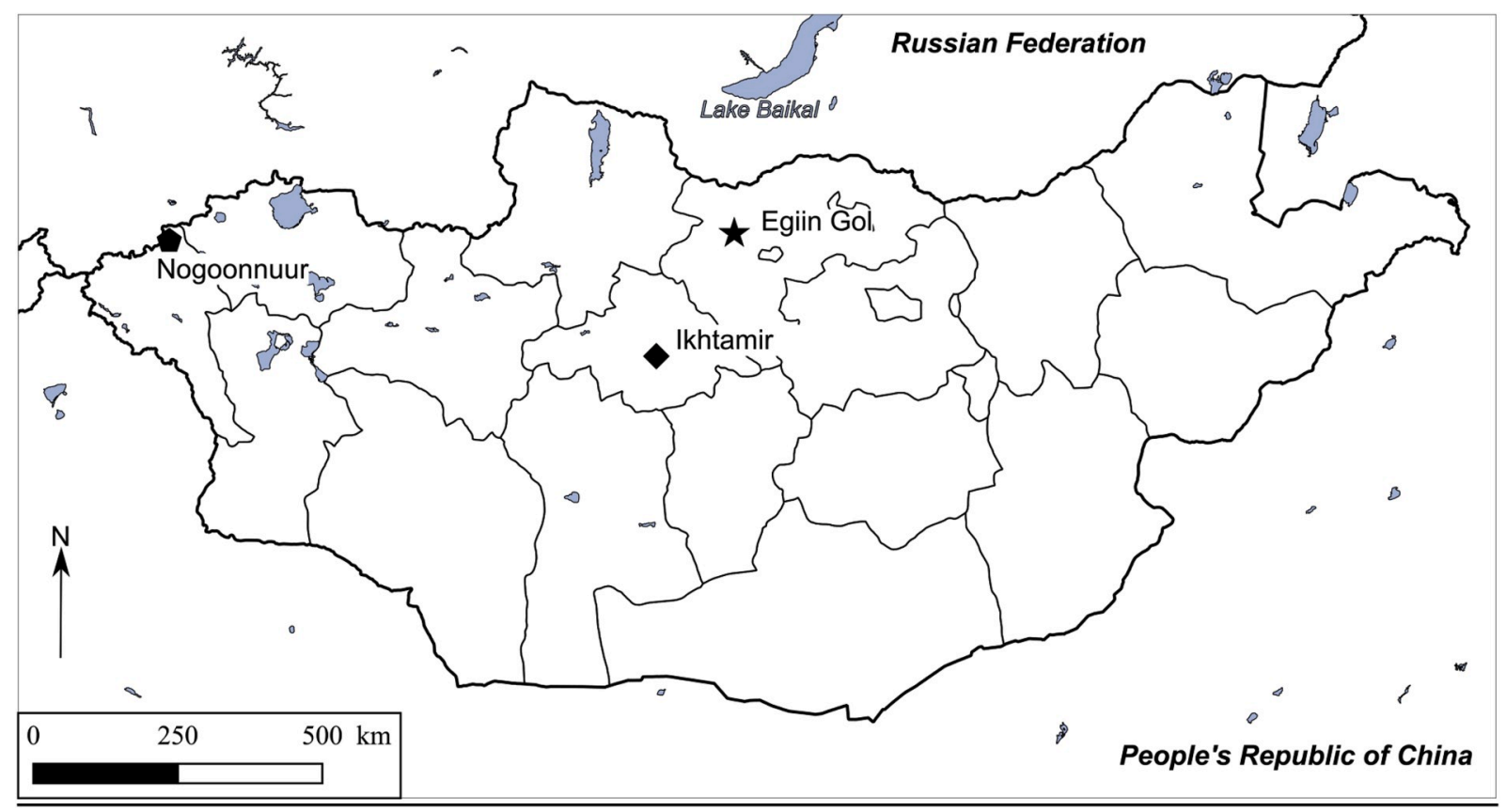

Fig. 1. Map of Mongolia showing the location of origin of the modern (Nogoonnuur and Ikhtamir) and archaeological (Egiin Gol) samples.

Table 1

Characteristics of the modern reference set used in the analyses. Approximate age at death (in months) was calculated assuming a birth date in March. DOD $=$ date of death.

\begin{tabular}{|c|c|c|c|c|c|c|c|}
\hline Sample & DOD & Year of birth & Approximate age at death (months) & Species & Origin & Sex & Tooth sampled \\
\hline Р2015-112 M3 & $18 / 06 / 2015$ & 2013 & 28 & Ovis aries & Nogoonnuur & ? & $\mathrm{M}_{3}$ \\
\hline P2015-147 M3 & $23 / 06 / 2015$ & 2013 & 28 & Capra hircus & Nogoonnuur & $?$ & $\mathrm{M}_{3}$ \\
\hline 2018-23A M3 & $29 / 06 / 2018$ & 2017 & 16 & Ovis aries & Nogoonnuur & M & $\mathrm{M}_{3}$ right \\
\hline 2018-63B M2 & $24 / 07 / 2018$ & 2016 & 28 & Ovis aries & Nogoonnuur & M & $\mathrm{M}_{2}$ left \\
\hline P330-M2 & $29 / 07 / 2013$ & 2012 & 16 & Ovis aries & Ikhtamir & $?$ & $\mathrm{M}_{2}$ right \\
\hline P331-M3 & $29 / 07 / 2013$ & 2011 & 29 & Ovis aries & Ikhtamir & $?$ & $\mathrm{M}_{3}$ left \\
\hline Alt16-104a M3 & $05 / 09 / 2016$ & 2014 & 30 & Ovis aries & Nogoonnuur & M & $\mathrm{M}_{3}$ left \\
\hline Alt16-283a M3 & $13 / 09 / 2016$ & 2014 & 30 & Ovis aries & Nogoonnuur & M & $\mathrm{M}_{3}$ left \\
\hline Alt16-306a M3 & $14 / 09 / 2016$ & 2014 & 30 & Ovis aries & Nogoonnuur & M & $\mathrm{M}_{3}$ left \\
\hline Alt16-369a M3 & $21 / 09 / 2016$ & 2014 & 30 & Capra hircus & Nogoonnuur & M & $\mathrm{M}_{3}$ left \\
\hline 2017-70 М3 & $17 / 11 / 2017$ & 2015 & 32 & Ovis aries & Nogoonnuur & M & $\mathrm{M}_{3}$ left \\
\hline 2017-71 М3 & $17 / 11 / 2017$ & 2015 & 32 & Capra hircus & Nogoonnuur & M & $\mathrm{M}_{3}$ left \\
\hline 2017-98 M3 & $20 / 11 / 2017$ & 2015 & 32 & Capra hircus & Nogoonnuur & M & $\mathrm{M}_{3}$ left \\
\hline 2017-146 М3 & $23 / 11 / 2017$ & 2015 & 32 & Capra hircus & Nogoonnuur & M & $\mathrm{M}_{3}$ left \\
\hline
\end{tabular}

et al., 2019). Among them, the Xiongnu were a confederation of nomadic or semi-nomadic herders who lived in the eastern steppes of present-day Mongolia, southern Siberia, northern China and Xinjiang. Many necropolises of this period have been excavated, and one of them, Egiin Gol (northern Mongolia), has been studied in detail (e.g. Crubézy et al., 1996; Giscard et al., 2013; Wright et al., 2009). The necropolis, which contains hundreds of tombs, is located in the Peri-Baikal region, in the north of Mongolia ( $49^{\circ} 26^{\prime} \mathrm{N}$. $103^{\circ} 30^{\prime} \mathrm{E}$.; Fig. 1), in the province of Bulgan and the district of Khutag-Öndör. The tombs are demarcated on their surface by piles of stones. They are mostly oriented north-south. A wooden chest placed at the north side, above the head, contains various offerings (e.g. ceramics, culinary sticks, and part of the spine - lumbar vertebra, sacrum and caudal vertebrae - of horses, caprines and bovines). Animal remains, including skulls and mandibles of horse, cattle, sheep and goat are also found in a niche situated behind this wooden chest. Two tombs (T77 and T60b) were selected for this study. The offering chest of T77 yielded a complete goat cut into 8 or 9 pieces, as well as elements of the lower limbs of a cattle. The niche of T60b was the richest of the site. It yielded remains belonging to 3 horses, 5 oxen, 18 goats (many of them very young) and 3 sheep. Interestingly, all hyoid bones were present, attesting that the flesh was still attached to the skull and that the animals were deposited rapidly following slaughter (Lepetz and Decanter, 2013). Stratigraphic data indicate that the deposits were made in a single event, probably contemporaneous to the individual's death. The goat third mandibular molars from T77 $(n=1)$ and T60b $(n=2)$ were not fully mineralised and were selected for stable isotope analysis (Table 2).

\section{Methods}

\subsection{Tooth enamel sampling and isotopic analysis}

Teeth surfaces were cleaned by abrasion with tungsten drill bits to remove the cement. Sequential sampling of modern and archaeological teeth was performed on the buccal side of the second and third molars, on the anterior lobe of $\mathrm{M} / 2$ and the middle lobe of $\mathrm{M} / 3$. The sampling spans the width of a lobe. Enamel was drilled with a diamond bit, perpendicular to the tooth growth axis from the apex to the enamel-root junction (ERJ). Samples were taken every $1.5-2 \mathrm{~mm}$ through the entire thickness of the enamel layer, and care was taken to avoid collecting the underlying dentine. Sample position was recorded in terms of distance (in $\mathrm{mm}$ ) from the ERJ when the tooth was in final development stage 
Table 2

Summary statistics of the isotopic values of enamel bioapatite samples. $\mathrm{N}=$ number of sub-samples taken from the tooth.

\begin{tabular}{llllll}
\hline Tooth label & $\mathrm{N}$ & \multicolumn{2}{l}{$\delta^{18} \mathrm{O}(\%$ V-PDB $)$} & \\
\cline { 2 - 6 } & & Mean $\pm \mathrm{SD}$ & Max & Min & Amplitude \\
\hline P330-M2 & 19 & $-8.97 \pm 6.0$ & -0.71 & -16.83 & 16.12 \\
P331-M3 & 15 & $-9.21 \pm 4.9$ & -0.85 & -15.21 & 14.36 \\
P2015-112 M3 & 22 & $-8.65 \pm 4.1$ & -2.37 & -13.87 & 11.50 \\
P2015-147 M3 & 21 & $-7.56 \pm 4.0$ & -0.38 & -12.35 & 11.97 \\
Alt16-104a M3 & 24 & $-7.66 \pm 3.8$ & -1.45 & -13.42 & 11.97 \\
Alt16-283a M3 & 24 & $-8.66 \pm 3.1$ & -3.35 & -13.79 & 10.44 \\
Alt16-306a M3 & 24 & $-7.39 \pm 3.3$ & -2.15 & -13.17 & 11.02 \\
Alt16-369a M3 & 18 & $-5.79 \pm 4.4$ & -0.14 & -12.3 & 12.16 \\
2017-70 M3 & 20 & $-7.64 \pm 3.1$ & -3.18 & -12.36 & 9.18 \\
2017-71 M3 & 20 & $-7.19 \pm 3.2$ & -3.18 & -12.39 & 9.21 \\
2017-98 M3 & 17 & $-8.22 \pm 3.4$ & -3.31 & -13.11 & 9.8 \\
2017-146 M3 & 24 & $-7.69 \pm 3.3$ & -2.26 & -12.59 & 10.33 \\
2018-23A M3 & 19 & $-8.77 \pm 3.8$ & -2.33 & -13.27 & 10.94 \\
2018-63B M2 & 18 & $-10.374 \pm 2.1$ & -6.53 & -13.00 & 6.47 \\
\hline T60b-P80 M3 ${ }^{\text {a }}$ & 17 & $-7.41 \pm 3.4$ & -1.50 & -11.67 & 10.17 \\
T60b-P82 M3 ${ }^{\text {a }}$ & 19 & $-7.13 \pm 3.4$ & -1.84 & -12.05 & 10.21 \\
T77-P90 M3 ${ }^{\text {a }}$ & 22 & $-8.04 \pm 2.7$ & -4.44 & -11.84 & 7.41
\end{tabular}

a archaeological samples.

(maturation phase), or from the base of the tooth crown when the tooth was still growing in length at the time of death.

Samples weighing $3.5-7 \mathrm{mg}$ were chemically treated following the procedure described in Balasse et al. (2002). First, organic matter was removed with a solution of $2-3 \% \mathrm{NaOCl}(24 \mathrm{~h}, 0.1 \mathrm{ml}$ solution/mg of sample) and rinsed several times in distilled water (although bleaching can induce a shift in $\delta^{18} \mathrm{O}$ values [see, for example, Koch et al., 1997], it not an issue here because the method used relies on relative, not absolute $\delta^{18} \mathrm{O}$ values). Then, each enamel sample was reacted with $0.1 \mathrm{M}$ acetic acid ( $4 \mathrm{~h}, 0.1 \mathrm{ml}$ solution/mg of sample) to remove exogenous carbonates, rinsed in distilled water and dried in an oven at $80^{\circ} \mathrm{C}$ for $12 \mathrm{~h}$. The same protocol was applied to both the modern and the archaeological samples to avoid biases due to pre-treatment-induced changes in the $\delta^{18} \mathrm{O}$ values of enamel (Balasse et al., 2012; Koch et al., 1997).

Purified enamel samples were weighed, and approximately $600 \mu \mathrm{g}$ of each sample was analysed on a Kiel IV device connected to a Delta V Advantage isotope ratio mass spectrometer (IRMS), at the Service de Spectrométrie de Masse isotopique du Muséum national d'histoire naturelle (SSMIM) in Paris. Analytical precision was $0.04 \%$ based on the repeated $(n=160)$ analysis of our internal laboratory carbonate standard (Marbre LM) normalised to NBS 19. Isotope data are presented in $\delta$ notation $\left[\delta=\left(R_{\text {sample }} / R_{\text {standard }}\right)-1\right]$, with $R$ the isotope ratio $\left({ }^{18} \mathrm{O} /{ }^{16} \mathrm{O}\right)$ of the sample, reported relative to the international standard V-PDB (Vienna PeeDee Belemnite) and expressed in per mil (\%o).

\subsection{Modelling sequential $\delta^{18} \mathrm{O}$ series and inference of the date of slaughter}

We tested the differences in isotopic values among individuals and sites using Kruskal-Wallis tests for modern and archaeological individuals separately.

Oxygen isotope sequences, recording the seasonal cycle of temperature, usually follow a sinusoidal pattern. For each individual animal, we modelled the oxygen isotope sequences using an equation derived from a cosine function proposed by Balasse et al. (2012):

$\delta^{18} O_{m}=A e^{\left(\frac{x-x_{B}}{x_{A}}\right)} \cos \left(2 \pi \frac{x-x_{0}}{X+b x}\right)+M+p x$

where $\delta^{18} \mathrm{O}_{\mathrm{m}}$ is the modelled $\delta^{18} \mathrm{O}$ value and $x$ is the distance of the sample to the ERJ. The following four parameters are key to describing the individual $\delta^{18} \mathrm{O}$ sequences: $X$ is the period (in $\mathrm{mm}$ ) of the cycle and corresponds to the length of tooth crown potentially formed over the period of 1 year, $A$ is the amplitude of the isotopic signal $[=(\max -\min ) /$ 2] (in \%), $M$ is the mean, $x_{0}$ is the position of the highest $\delta^{18} \mathrm{O}$ values in the tooth crown. The last four parameters have less influence: $p$ is the slope (in \%.mm ${ }^{-1}$ ) of the mean; when the sequence measured spans more than 1 year, the mean $\mathrm{M}$ may change from year to year (change in the mean annual ambient temperature, for example). $x_{A}$ and $x_{B}$ (in $\mathrm{mm}$ ) model the attenuation of the amplitude $\mathrm{A}$, and $b$ is the gradation of the period (no unit). Values were fixed to 0 for $p$ and $x_{B}$ and to $10^{6}$ for $x_{A}$ (Balasse et al., 2012). Parameter $b$ was also introduced in the model because it helps to describe the attenuation of the growth rate from the apex to the neck of the crown on the third molar. We also used it for the second molar, even though it has less influence, in order to compare the models based on these two types of teeth. For each sample, parameter estimation was performed using an iterative method, performed in Microsoft Excel, based on the method of minimisation of the least squares (for more information on method estimation, including the comparison of three alternative versions of the model, see Appendix A).

Because the cycles in the sinusoidal modelled sequence (SMS) have a period of 1 year, there is a simple and direct proportional relationship between the position $P$ of a sample on the SMS and the date d (in days) to which it corresponds, such as:

$d=P\left({ }^{\circ}\right) \times \frac{365.25}{360}$

$P$ is the position (in degrees) in the annual cycle, with $\mathrm{P}=0^{\circ}$ for the lowest $\delta^{18} \mathrm{O}$ value of each sequence, and $d$ is the number of days elapsed since $\mathrm{P}=0^{\circ}$. We propose that $\mathrm{P}=0^{\circ}$ corresponds to the Mongolian midwinter (January 15) and that $\mathrm{P}=180^{\circ}$ corresponds to the Mongolia midsummer (July 17; see Appendix B). To obtain direct estimates of the number of days since the first day of a calendar year (i.e. January 1), Eq. (2) can be modified as follows:

$d=P\left({ }^{\circ}\right) \times \frac{365.25}{360}+15$

where the number 15 corresponds to the number of days between January 1 and January 15. DOD can then be calculated by applying Eq. (3) to the position (in ${ }^{\circ}$ ) of the $\delta^{18} \mathrm{O}$ values at the ERJ $\left(\delta_{\mathrm{f}}\right)$. To precisely calculate the position $\left(P_{\mathrm{f}}\right)$ of $\delta_{\mathrm{f}}$ in the annual cycle, we used one of the following two equations, depending on whether the end of the modelled SMS was in the increasing (Eq. (4)) or the decreasing phase (Eq. (5)):

$P_{f}\left({ }^{\circ}\right)=\left(\frac{\delta_{f}-\delta_{\min }}{2 A}\right) \times 180$

$P_{f}\left({ }^{\circ}\right)=\left(\frac{\delta_{0}-\delta_{f}}{2 A}\right) \times 180+180$

where $\delta_{0}$ is the highest $\delta^{18} \mathrm{O}$ value in the SMS and $\delta_{\min }$ is the lowest $\delta^{18} \mathrm{O}$ value.

We tested the accuracy of our approach by comparing the known and calculated DOD through a linear regression between the two sets of dates. We calculated the standard error of the estimated DOD of our samples as follows:

$\sigma=\sqrt{\frac{\left(D O D_{c}-D O D_{k}\right)^{2}}{N-2}}$

where $\sigma$ is the standard error of the estimate, $D O D_{c}$ is the estimated DOD, $D O D_{k}$ is the known DOD and $\mathrm{N}$ is the number of samples.

\subsection{Age estimation of the archaeological goats}

The age of the archaeological goats from T77 and T60b was estimated by combining the analysis of tooth eruption stages and tooth wear patterns (Grant, 1982; Jones, 2006). Because inter-individual variation in tooth wear and tooth eruption patterns can impact age-at-death 
estimation, the uncertainty of the age estimate is 2 months for individuals $<6$ months old, and the uncertainty increases with the age of the animal (Greenfield and Arnold, 2008; Jones, 2006).

Unless mentioned otherwise, all statistical analyses were performed in Past version 3.24.

\section{Results and discussion}

4.1. Inter- and intra-individual variability in the $\delta^{18} \mathrm{O}$ sequences of the modern reference set

The results of the stable isotope analysis are presented in Appendix Tables C.1 to C.5.2. The average $\delta^{18} \mathrm{O}$ value of all samples was $-8.1 \pm 1.1 \%$ o $(1 \sigma)$, with a maximum value of $-5.8 \%$ and a minimum value of $-10.4 \%$ per individual, on average. The lowest and highest $\delta^{18} \mathrm{O}$ values were $-16.8 \%$ and $-0.1 \%$, respectively. Intra-individual

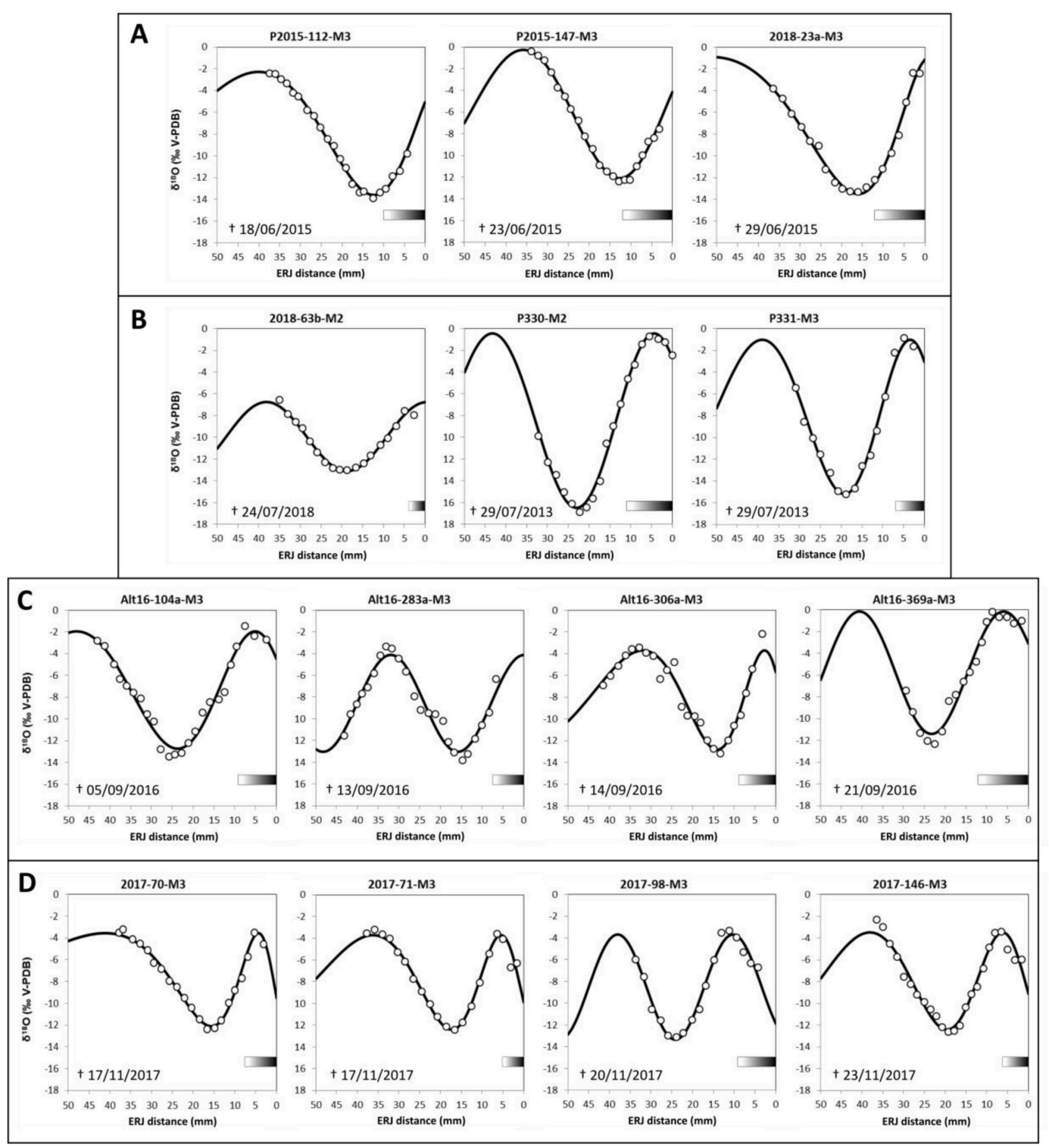

Fig. 2. Variations in oxygen isotope values along the tooth crown of the modern sheep and goat molars. The position of the sample is expressed as the distance between the sample and the enamel-root junction (ERJ). The circles represent the measured data, and the black line is the best sinusoidal model that fits the data. Each panel represents a different slaughter period: late June (A), late July (B), September (C) and November (D). The grey shaded areas indicate the extent of immature enamel along the tooth crown. 
variability was $11.1 \pm 2.3 \%$ on average, with a maximum of $16.1 \%$ and a minimum of $6.5 \%$. Maximum values ranged between $-6.5 \%$ and $-0.1 \%$, and minimum values ranged between $-16.8 \%$ and $-12.3 \%$ (Table 2). The large amplitude of seasonal $\delta^{18} \mathrm{O}$ variation of modern teeth is representative of the marked continental climate with little annual precipitation $(\sim 131 \mathrm{~mm})$, typical of Mongolia. The oxygen isotopic values from the two locations, Nogoonnuur $(n=253)$ and Ikhtamir $(n=33)$, were not statistically different (One-way ANOVA, pvalue $=0.27$, with mean values of $-7.4 \pm 8.6 \%$ and $-9.1 \pm 5.5 \%$, respectively.

For each individual, $\delta^{18} \mathrm{O}$ sequences showed large intra-tooth variation, following a sinusoidal pattern (Fig. 2). The position of the last $\delta^{18} \mathrm{O}$ values within the sinusoidal curve of each tooth $\left(\delta_{\mathrm{f}}\right)$ differed depending on the slaughtering period. Indeed, sinusoidal patterns were in an increasing phase for the three individuals slaughtered in late June (Fig. 2A). They reached a plateau for individuals slaughtered between late July (Fig. 2B) and September (Fig. 2C). Finally, they were in an advanced decreasing phase for animals slaughtered in November (Fig. 2D). Nevertheless, we noticed similarities in the isotope profiles of some animals that were slaughtered more than a few weeks apart (e.g. P330 vs Alt16-104a; Alt16-306a vs 2017-70).

\subsection{Accuracy of the modelled DOD}

Parameters selected for the models of best fit are presented in Table 3. For each tooth, Pearson's correlation coefficient of the model was greater than or equal to 0.97 (Table 3). There was at least one minimum for each sequential series, and most sequences showed one maximum and one minimum along the tooth crown. We chose the minimum value corresponding to the winter immediately preceding the animal's slaughter, which was observed in all specimens, as the starting point $\left(=0^{\circ}\right)$ of the annual cycle.

Calculated DOD range from 137.7 to $352.6 \mathrm{~d}$ (from January 1) whereas known DOD range from 169 to $327 \mathrm{~d}$ (Table 3). The absolute difference between modelled and known DOD is $18.6 \pm 14.7 \mathrm{~d}$ on average, and ranges from 3.9 to $59.4 \mathrm{~d}$. There is no statistical difference between sheep and goat (One-way ANOVA, p-value $=0.68$ ), with mean values of $17.4 \pm 16.6 \mathrm{~d}$ and $20.9 \pm 11.8 \mathrm{~d}$, respectively. There was a strong linear relationship between modelled (Table 3 ) and known DOD (Fig. 3):

$y=1.07( \pm 0.11) x-23.90( \pm 29) \quad R^{2}=0.88 \quad p=6.46 e^{-07 * * *}$

Differences in the known DOD of individual slaughtered a few days from each other explains only a small part of the variability measured in the $P$ of $\delta_{\mathrm{f}}$ of individuals slaughtered a few days from each other. As a result, standard deviation in the known DOD of these individuals, slaughtered in a different period, ranged from 3 to $7 \mathrm{~d}$, while standard deviation in the calculated DOD ranged from 15 to $29 \mathrm{~d}$ (Table 3). This additional variability could come from differences in physiology, such as body water balance, or in differences in the rate of mineralisation as tooth growth proceeds. To assess the possible influence of the mineralisation stage, we measured the length of immature enamel and the length of apposition on the developing molars (see Appendix Table D). Indeed, the appositional layer $(L a)$ marks the first layer of enamel deposited during the secretion stage (Suga, 1982; Zazzo et al., 2012). When the tooth approaches its maximum length and the growth rate

Table 3

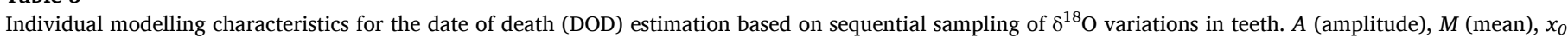

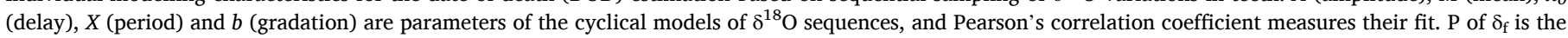

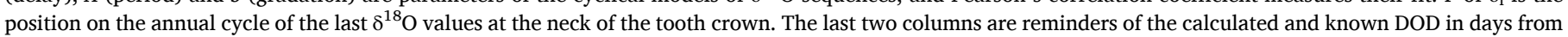
January 1.

\begin{tabular}{|c|c|c|c|c|c|c|c|c|c|c|c|c|c|}
\hline Sample & $\begin{array}{l}A \\
(\% 0)\end{array}$ & $\begin{array}{l}M \\
(\%)\end{array}$ & $\begin{array}{l}x_{0} \\
(\mathrm{~mm})\end{array}$ & $\begin{array}{l}X \\
(\mathrm{~mm})\end{array}$ & $\begin{array}{l}b \text { (no } \\
\text { unit) }\end{array}$ & $\begin{array}{l}\text { Pearson's } \\
\text { corr. coeff. } \\
\text { r }\end{array}$ & $\delta_{\mathrm{f}}(\% 0)$ & $\begin{array}{l}P \text { of } \delta_{\mathrm{f}} \\
\left({ }^{\circ}\right)\end{array}$ & $\begin{array}{l}\text { Calculated } \\
\text { DOD }\end{array}$ & $\begin{array}{l}\text { Known } \\
\text { DOD }\end{array}$ & $\begin{array}{l}\text { Period of } \\
\text { death }\end{array}$ & $\begin{array}{l}\text { Mean } \pm \text { SD } \\
\text { calculated } \\
\text { DOD per } \\
\text { period }\end{array}$ & $\begin{array}{l}\text { Mean } \pm \text { SD } \\
\text { known DOD } \\
\text { per period }\end{array}$ \\
\hline $\begin{array}{l}\text { P2015-112 } \\
\text { M3 }\end{array}$ & 5.66 & -7.96 & 40.0 & 47.93 & 0.60 & 0.998 & -5.1 & 135.6 & 152.6 & 169 & Late June & $162 \pm 29$ & $174 \pm 6$ \\
\hline $\begin{array}{l}\text { P2015-147 } \\
\text { M3 }\end{array}$ & 5.93 & -6.17 & 35.82 & 44.45 & 0.15 & 0.997 & -4.1 & 121.0 & 137.7 & 174 & & & \\
\hline $\begin{array}{l}\text { 2018-23a } \\
\text { M3 }\end{array}$ & 6.30 & -7.19 & -1.08 & 26.0 & 0.51 & 0.993 & -1.1 & 176.9 & 194.5 & 180 & & & \\
\hline $\begin{array}{l}\text { 2018-63b } \\
\text { M2 }\end{array}$ & 3.18 & -9.92 & -0.51 & 38.66 & 0 & 0.990 & -6.8 & 179.7 & 197.3 & 205 & Late July & $215 \pm 15$ & $208 \pm 3$ \\
\hline P330-M2 & 8.02 & -8.26 & 4.39 & 35.39 & 0.09 & 0.997 & -2.7 & 205.7 & 223.7 & 210 & & & \\
\hline P331-M3 & 7.09 & -7.90 & 3.45 & 27.77 & 0.2 & 0.994 & -3.1 & 206.0 & 224 & 210 & & & \\
\hline $\begin{array}{l}\text { Alt16-104a } \\
\text { M3 }\end{array}$ & 5.41 & -7.34 & 5.12 & 31.81 & 0.23 & 0.983 & -4.5 & 222.2 & 240.4 & 247 & September & $230 \pm 22$ & $257 \pm 7$ \\
\hline $\begin{array}{l}\text { Alt16-283a } \\
\text { M3 }\end{array}$ & 4.44 & -8.58 & -0.08 & 31.72 & 0.01 & 0.968 & -4.1 & 180 & 197.6 & 257 & & & \\
\hline $\begin{array}{l}\text { Alt16-306a } \\
\text { M3 }\end{array}$ & 4.57 & -8.27 & 2.75 & 17.65 & 0.36 & 0.973 & -5.7 & 219.7 & 237.9 & 258 & & & \\
\hline $\begin{array}{l}\text { Alt16-369a } \\
\text { M3 }\end{array}$ & 5.64 & -5.77 & 5.96 & 34.71 & 0 & 0.986 & -3.1 & 227.5 & 245.8 & 265 & & & \\
\hline $\begin{array}{l}\text { 2017-70 } \\
\text { M3 }\end{array}$ & 4.27 & -7.85 & 4.35 & 13.83 & 0.56 & 0.993 & -9.53 & 305.4 & 324.9 & 321 & November & $329 \pm 17$ & $323 \pm 3$ \\
\hline $\begin{array}{c}\text { 2017-71 } \\
\text { M3 }\end{array}$ & 4.34 & -8.06 & 5.49 & 17.19 & 0.38 & 0.987 & -9.89 & 307.9 & 327.4 & 321 & & & \\
\hline $\begin{array}{c}2017-98 \\
\text { M3 }\end{array}$ & 4.83 & -8.50 & 10.33 & 27.70 & 0 & 0.987 & -11.89 & 332.8 & 352.6 & 324 & & & \\
\hline $\begin{array}{l}\text { 2017-146 } \\
\text { M3 }\end{array}$ & 4.46 & -7.96 & 6.22 & 21.29 & 0.28 & 0.979 & -9.1 & 293.7 & 313 & 327 & & & \\
\hline $\begin{array}{c}\text { T60b-P80 } \\
\text { M3 }{ }^{\mathrm{a}}\end{array}$ & 4.94 & -6.62 & 6.00 & 30.62 & 0.05 & 0.997 & -5.07 & 239.9 & 258.4 & & & & \\
\hline $\begin{array}{c}\text { T60b-P82 } \\
\text { M3 }{ }^{\text {a }}\end{array}$ & 5.08 & -6.61 & 3.16 & 14.62 & 0.61 & 0.993 & -5.5 & 251.0 & 269.6 & & & & \\
\hline $\begin{array}{c}\text { T77-P90 } \\
\text { M3 }\end{array}$ & 3.83 & -8.13 & 26.68 & 23.88 & 0.18 & 0.974 & -4.89 & 192.9 & 210.7 & & & & \\
\hline
\end{tabular}

a archaeological samples. 


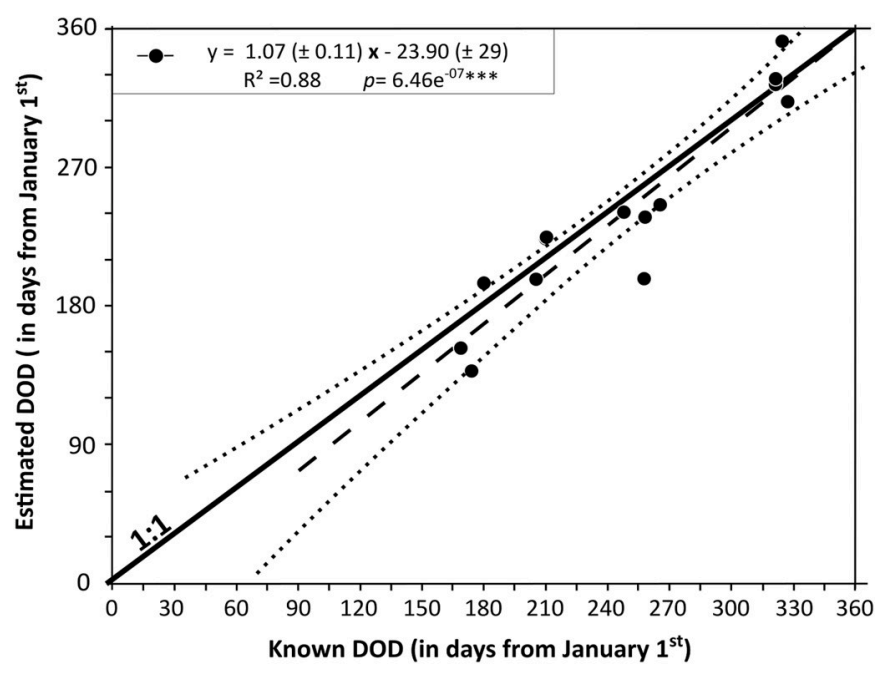

Fig. 3. Calculated date of death (DOD) plotted against the known DOD (black circles). The corresponding linear regression line (ordinary least square regression; dashed line) is shown, along with associated $95 \%$ confidence bands (dotted lines). The linear regression is compared with the expected slope 1:1 of perfect match between calculated DOD and known DOD (thick black line).

decreases, the length of this newly accreted enamel layer decreases. This appositional layer records the isotopic signal closest to the animal's death, so the longer this zone is, the closer we should be to the known DOD. However, we found no relationship between $L a$ length and the absolute difference between the modelled and the known DOD (Pearson's $r=-0.19 ; \mathrm{r}^{2}=0.04 ; p$-value $=0.6$ ). Alternatively, variability in modelled DOD could come from inter-individual differences in the $\delta^{18} \mathrm{O}$ value of the input signal, with differences in the relative proportion of sources of ingested water (e.g. snow, plant water, drinking water, well water) across a year, leading to differences in the $\delta_{\mathrm{f}}$ values and variation of the seasonal amplitude from one year to the next. Unfortunately, these parameters were not controlled for in our study.

Overall, the standard error of the calculated DOD in our modern reference set was less than 1 month $(1 \sigma= \pm 25 \mathrm{~d})$. This uncertainty is time-independent, unlike other methods, in which precision remains qualitative and can vary depending on the time of the year (i.e. cementochronology; Burke and Castanet, 1995; Nývltová Fišáková, 2013; Schmaus et al., 2019) or the age of the animal (i.e. tooth wear and eruption stages; Greenfield and Arnold, 2008; Jones, 2006). Moreover, the main advantage of the isotopic approach is that it does not rely on any assumptions, such as the type of food resources (unlike the tooth microwear method) or the date of birth of the animal (unlike the tooth wear and eruption stages method).

\subsection{Archaeological application}

\subsubsection{Estimation of the date of death}

Tooth enamel $\delta^{18} \mathrm{O}$ values from the three archaeological specimens ranged from $-1.5 \%$ to $-12.1 \%$ (mean $-7.5 \pm 0.5 \%$ ) (Table 2 ). Intraindividual variability ranged from $7.4 \%$ to $10.2 \%$. For each specimen, maximum values ranged from $-4.4 \%$ to $-1.5 \%$ and minimum values ranged from $-12.1 \%$ to $-11.7 \%$ (Table 2 ). Complete results are presented in Appendix Table C.6 There were no significant differences among the three archaeological individuals (one-way ANOVA, pvalue $=0.5$ ) or between the modern and the archaeological individuals (one-way ANOVA, $\mathrm{p}$-value $=0.9$ ).

Parameters selected for the models of best fit of the sequential $\delta^{18} \mathrm{O}$ sequences of archaeological specimens (Fig. 4) are presented in Table 3. The positions $P$ of $\delta_{\mathrm{f}}$ values on the annual cycle were $239.9^{\circ}, 251.0^{\circ}$ and $192.9^{\circ}$ for T60b-P80, T60b-P82 and T77-P90, respectively. Calculated DOD were September 15 and September 26 for the two individuals in T60b and July 29 for the individual in T77 (Fig. 5). Given the uncertainty of our method $( \pm 29 \mathrm{~d})$, calculated DOD for the two individuals from Tomb 60b were not significantly different and indicated that the individuals were buried in autumn, slightly later than the individual from Tomb 77, which was buried in summer.

Among nomadic peoples, death can occur at a time of year when the human group is far from the family burial place (when there is one). Therefore, there may be a delay between the death of an individual and their burial. Being able to precisely determine the period of the year during which the bodies were placed in the ground is therefore of great importance to document the mobility of these populations and their funerary practices and the date of death of the caprines deposited in the tomb can be used as a proxy for when the humans were buried. Previous attempts at determining burial periods at Egiin Gol were based on cementochronology (Crubézy et al., 1996) on the animal teeth from tomb 15 and the tooth eruption and wear stages (Lepetz and Decanter, 2013) on the animal from tomb 60b. These studies suggested that animal slaughtering occurred during the warm season. Our results are in good agreement with this interpretation. The proposed date of death for T60b corresponds to a time when temperatures are already decreasing but where the soil is not yet frozen and can be easily dug (Dashtseren et al., 2014; Nandintsetseg and Shinoda, 2011), in accordance with what is generally assumed. In addition, our preliminary results suggest that the funerals of the human individuals in T77 and T60b did not take place at the same time of year. More work is required to extend these preliminary results to the entire necropolis.

\subsubsection{Seasonality of birth}

Because the individuals from T60b and T77 were deposited fresh, one can assume that they were buried immediately following slaughter.
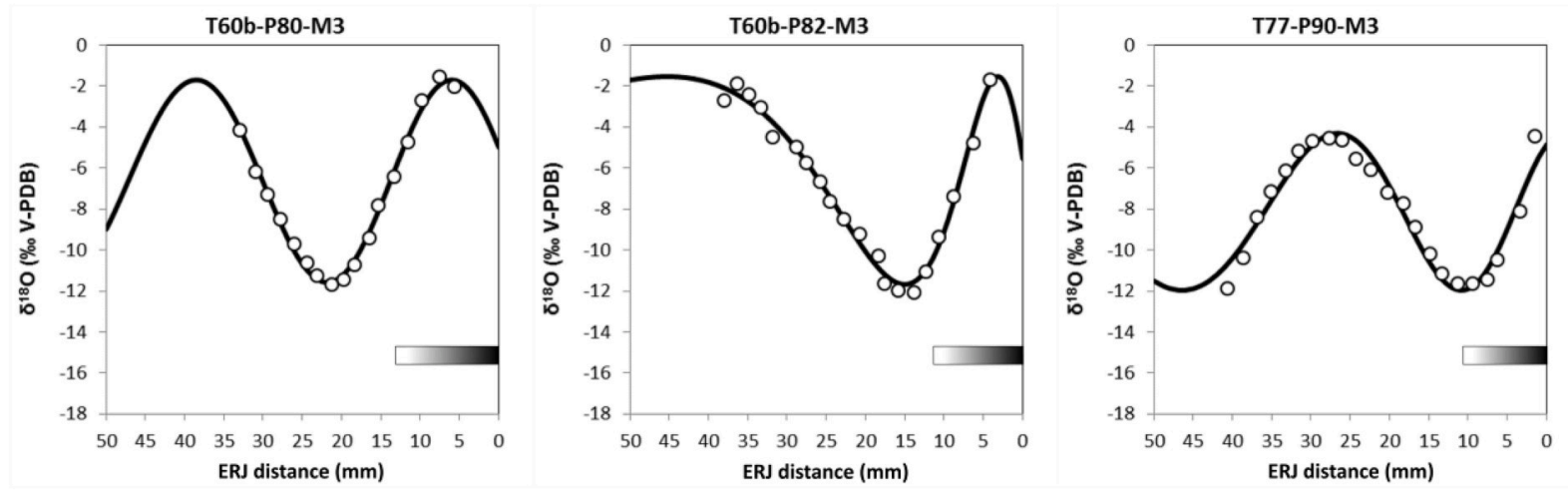

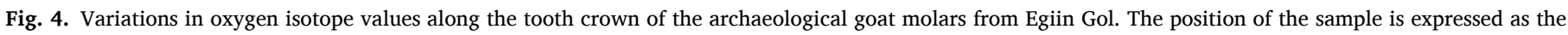

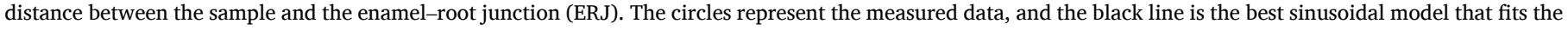
data. The grey shaded areas indicate the extent of immature enamel along the tooth crown. 


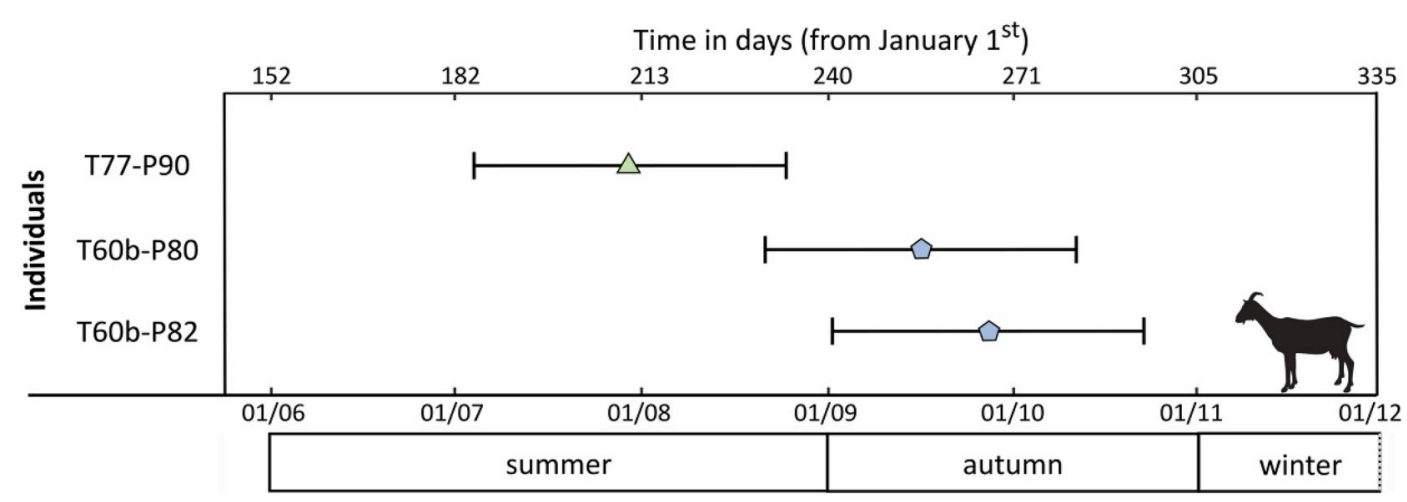

Calendar date

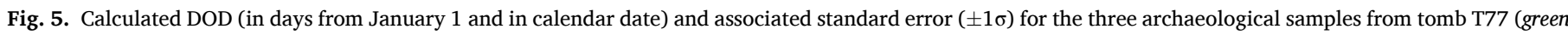
triangle) and tomb T60b (blue pentagon) at Egiin Gol.

Thus, we can use the DOD estimate to reconstruct the seasonality of birth of the caprines deposited in these graves. We base our reconstruction on individuals found in tomb T60b because it was one of the richest of the site and delivered the remains of 21 caprines. Tooth wear and eruption stages provided an estimated age of 18 and 20-24 months old for individuals P80 and P82, respectively. The proposed age for 10 other young goats varies between $4 \pm 1$ and $11 \pm 2$ months old on average (see Appendix Table $\mathrm{E}$ for eruption and wear stages and age-atdeath determination).

To precisely reconstruct the seasonality of birth, we used only the youngest ( $<18$ months old) goats from this tomb $(n=11)$, for which the error associated with the estimation of their age is the lowest (Fig. 6). Assuming a slaughter date of September 20, the lambing season would extend from November to May, with a peak in April (Fig. 6). This is consistent with the data collected from modern herders, which indicates that parturition takes place from February to May, with a peak between late March and mid-April. Today, Mongolian herders tend to favour relatively early births among sheep and goats, so as to give the young time to grow strong enough by the end of autumn (Legrand, 2011, 219).

\subsection{Physiological, ecological and environmental limits of the method}

Although promising, there are several limitations to the use of the isotope method of determination of DOD. Because this method requires individuals with developing teeth, the first obvious limitation is the age of animal itself. Animals should not be too old, because the enamel would have already stopped growing at the time of death, but they should not be too young either, because the enamel needs to record at least one full isotopic cycle. The first molars of caprines appear to be a poor prospect due to their rapid growth ( $\sim 6-9$ months) (Weinreb and Sharav, 1964; Zazzo et al., 2010) and wear (Hillson, 2005). The second and third molars are better candidates (Upex and Dobney, 2012, Fig. 2) and can be used to determine the DOD of animals between 9 months old and 2-3 years old. The method can be applied to other domestic species with high-crowned teeth, such as horse or cattle. However, due to a longer duration of enamel mineralisation for large ungulates, such as horse (Bendrey et al., 2015; Hoppe et al., 2004), it will be necessary to build reference sets for the species of interest before applying the method to ancient remains.

Animal drinking behaviours can also affect the $\delta^{18} \mathrm{O}$ sequences recorded in their teeth (Makarewicz and Pederzani, 2017). The main source of water is one of these factors. Non-obligate drinkers, such as sheep and goat, obtain their water preferentially from the plants they eat. Plant water $\delta^{18} \mathrm{O}$ values are strongly affected by evaporation, leading to large seasonal variations in tooth enamel $\delta^{18} \mathrm{O}$ values of caprines. In contrast, obligate drinkers obtain their water preferentially from lakes or rivers, which are commonly more isotopically stable through time. As a result, the seasonal variations recorded in tooth enamel are dampened (Darling et al., 2003; Halder et al., 2015; West et al., 2014), making DOD determination more hazardous. Pastoral practices, such as distribution of water from well digging, can also strongly reduce the $\delta^{18} \mathrm{O}$ amplitude recorded along the tooth crown, as suggested in various archaeological contexts by Dufour et al. (2014), Goepfert et al. (2013), and Henton et al. (2014), and limit the application of $\delta^{18} \mathrm{O}$ sequences for the determination of the period of death.

Environmental factors can also limit the application of this method. The approach proposed here is well suited to mid- and high-latitude sites where temperature is the main factor driving oxygen isotope variations

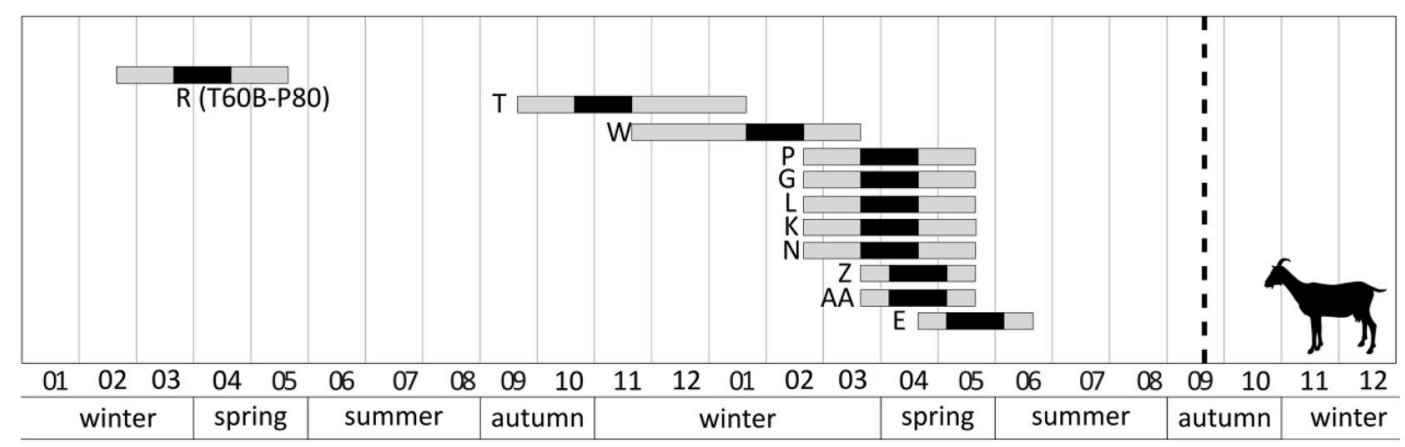

Date of birth (in months)

Fig. 6. Date of birth (black shading), with associated uncertainty (light grey shading) of the youngest archaeological goats from tomb 60b of the Egiin Gol necropolis based on the estimation of age at death by eruption and wear stages (see Appendix E) and using the DOD estimated (vertical dotted line) by the $\delta^{18} \mathrm{O}$ sequences of individuals R (T60b-P80, dark grey shading) and X (T60b-P82, not shown) (see Fig. 5). 
of precipitation (Dansgaard, 1964; Pederzani and Britton, 2019; Rozanski et al., 1993). It is probably not well suited to low latitude regions and areas characterised by monsoon activity, where air temperature remains essentially constant and precipitation $\delta^{18} \mathrm{O}$ values are primarily controlled by humidity (Dansgaard, 1964). An increase in precipitation and/or humidity causes $\delta^{18} \mathrm{O}$ of meteoric water to decrease (Dansgaard, 1964; Higgins and MacFadden, 2004; Rozanski et al., 1993; Straight et al., 2004). Thus, a decrease in tooth enamel $\delta^{18} \mathrm{O}$ values can potentially occur during the hottest months in locations where humidity maximum occurs during summer.

Finally, it is important to consider the potential impact of diagenesis when working on immature enamel. Immature enamel is not well mineralised and is more prone to isotope exchange with environmental carbonate, much like bone (Zazzo et al., 2004). We anticipate that a difference in the rate of isotopic exchange between mature and immature enamel will result in an isotopic discontinuity that should be easily detected. We did not observe any discontinuity along the isotopic curves between the mature and immature parts of the tooth enamel in the ancient teeth analysed here. So at least in our case (for fairly recent material found in grave contexts) there was no visible effect of diagenesis. For older or less well preserved material, an alternative would be to select the phosphate group instead, which is less prone to isotopic exchange than the carbonate group (Iacumin et al., 1996; Lee-Thorp, 2008; Zazzo et al., 2004).

\section{Conclusion}

In this study, we propose a method to determine the date of death of caprines based on $\delta^{18} \mathrm{O}$ analysis of developing tooth enamel. We show that this date can be estimated with an error of \pm 1 month $(1 \sigma)$, and we applied the method to determine the DOD of three goats found in two tombs from the Xiongnu cemetery at Egiin Gol, Mongolia. This allowed us to reconstruct the date of birth of the individual animals placed in the tomb based on their estimated age at death. Although the proposed method has shown its potential, it would be desirable to enlarge the modern reference dataset, in particular with animals slaughtered in winter and spring, in order to improve its accuracy. The method proposed here is restricted to young animals and may not be valid in different environmental contexts. With these limitations in mind, our method provides clues to explore animal management strategies in ancient pastoral societies and, more broadly, to reconstruct the exploitation of their environment by past mobile or sedentary societies. As such, it provides a complementary approach of traditional methods (cementogenesis, tooth microwear pattern and tooth wear and eruption sequence) for DOD studies that does not rely on any assumption regarding the type of food resources ingested or the date of birth of the animal.

\section{Declaration of competing interest}

None.

\section{Acknowledgements}

We are deeply indebted to all the herders who kindly participated to the study and to N. Bayarkhuu (Institute of History and Archaeology, Mongolian Academy of Sciences, Mongolia) for arranging the logistics and providing assistance during fieldwork. We would like to thank D. Vettese (UMR 7194 HNHP, MNHN, Paris) for her help in sampling and analysing archaeological samples from Egiin Gol, M. Balasse (UMR 7209 AASPE, MNHN, Paris) for her help with the modelling of the $\delta^{18} \mathrm{O}$ sequences, the two anonymous reviewers for their constructive comments and S. Needs-Howarth for editing the English. The isotopic analyses were performed at the SSMIM Paris under the technical supervision of D. Fiorillo. Fieldwork was supported by the French archaeological mission in Mongolia (CNRS, MNHN, MAEDI, director SL) and by the CNRS. This research was funded by a Ph.D. grant to NL from the French National Research Agency LabEx ANR-10-LABX-0003-BCDiv, in the context of the "Investissements d'avenir" n ${ }^{\circ}$ ANR-11-IDEX-0004-02, and by an Inalco Early Career Research Grant 2017 to CM.

\section{Appendix A. Supplementary data}

Supplementary data to this article can be found online at https://doi. org/10.1016/j.jas.2020.105163.

\section{References}

Balasse, M., 2003. Potential biases in sampling design and interpretation of intra-tooth isotope analysis. Int. J. Osteoarchaeol. 13, 3-10. https://doi.org/10.1002/oa.656.

Balasse, M., 2002. Reconstructing dietary and environmental history from enamel isotopic analysis: time resolution of intra-tooth sequential sampling. Int. J. Osteoarchaeol. 12, 155-165. https://doi.org/10.1002/oa.601.

Balasse, M., Ambrose, S.H., Smith, A.B., Price, T.D., 2002. The seasonal mobility model for prehistoric herders in the south-western Cape of South Africa assessed by isotopic analysis of sheep tooth enamel. J. Archaeol. Sci. 29, 917-932. https://doi.org/ 10.1006/jasc.2001.0787.

Balasse, M., Obein, G., Ughetto-Monfrin, J., Mainland, I., 2012. Investigating seasonality and season of birth in past herds: a reference set of sheep enamel stable oxygen isotope ratios. Archaeometry 54, 349-368. https://doi.org/10.1111/j.14754754.2011.00624.x.

Bendrey, R., Vella, D., Zazzo, A., Balasse, M., Lepetz, S., 2015. Exponentially decreasing tooth growth rate in horse teeth: implications for isotopic analyses. Archaeometry 57, 1104-1124. https://doi.org/10.1111/arcm.12151.

Bernard, A., Daux, V., Lécuyer, C., Brugal, J.-P., Genty, D., Wainer, K., Gardien, V., Fourel, F., Jaubert, J., 2009. Pleistocene seasonal temperature variations recorded in the $\delta^{18} \mathrm{O}$ of Bison priscus teeth. Earth Planet Sci. Lett. 283, 133-143. https://doi.org/ 10.1016/j.epsl.2009.04.005.

Burke, A., Castanet, J., 1995. Histological observations of cementum growth in horse teeth and their application to archaeology. J. Archaeol. Sci. 22, 479-493. https:// doi.org/10.1006/jasc.1995.0047.

Carter, R.J., 2001. Dental indicators of seasonal human presence at the Danish Boreal sites of holmegaard I, IV and V and Mullerup and the Atlantic sites of Tybrind Vig and Ringkloster. Holocene 11, 359-365. https://doi.org/10.1191/ 095968301667543765.

Crubézy, E., Martin, H., Giscard, P.-H., Batsaikhan, Z., Erdenebaatar, D., Maureille, B., Verdier, J.-P., 1996. Pratiques funéraires et sacrifices d'animaux en Mongolie á la période proto-historique. Du Perçu au signifié à propos d'une sépulture xiongnu de la vallée d'Egyin Gol (Région Péri-Baikal). Paleorient 89-107.

Dansgaard, W., 1964. Stable isotopes in precipitation. Tellus A 16, 438-468.

Darling, W.G., Bath, A.H., Talbot, J.C., 2003. The O and H stable isotope composition of freshwaters in the British Isles. 2. Surface waters and groundwater. Hydrol. Earth Syst. Sci. 7, 183-195. https://doi.org/10.5194/hess-7-183-2003.

Dashtseren, A., Ishikawa, M., Iijima, Y., Jambaljav, Y., 2014. Temperature regimes of the active layer and seasonally frozen ground under a Forest-steppe Mosaic, Mongolia. Permafr. Periglac. Process. 25, 295-306. https://doi.org/10.1002/ppp.1824.

Dufour, E., Goepfert, N., Léon, B.G., Chauchat, C., Jordán, R.F., Sánchez, S.V., 2014. Pastoralism in northern Peru during pre-Hispanic times: insights from the mochica period (100-800 AD) based on stable isotopic analysis of domestic Camelids. PloS One 9, e87559. https://doi.org/10.1371/journal.pone.0087559.

El Adli, J.J., Fisher, D.C., Vartanyan, S.L., Tikhonov, A.N., 2017. Final years of life and seasons of death of woolly mammoths from Wrangel Island and mainland Chukotka, Russian Federation. In: Quat. Int., VIth International Conference on Mammoths and Their Relatives, Part 3, vol. 445, pp. 135-145. https://doi.org/10.1016/j. quaint. 2016.07.017.

Ervynck, A., 2005. Detecting the seasonal slaughtering of domestic mammals: inferences from the detailed recording of tooth eruption and wear. Environ. Archaeol. 10, 153-169. https://doi.org/10.1179/env.2005.10.2.153.

Fisher, D.C., Fox, D.L., 2007. Season of death of the dent mammoths. Dent Prairie peaks rock. Recent Paleoindian Res. Colo. 123-153.

Fisher, D.C., Fox, D.L., Agenbroad, L.D., 2003. Tusk growth rate and season of death of Mammuthus columbi from Hot Springs, South Dakota, USA. Deinsea 9, 117-134.

Fricke, H.C., O'Neil, J.R., 1999. The correlation between ${ }^{18} \mathrm{O} /{ }^{16} \mathrm{O}$ ratios of meteoric water and surface temperature: its use in investigating terrestrial climate change over geologic time. Earth Planet Sci. Lett. 170, 181-196.

Fricke, H.C., O'Neil, J.R., 1996. Inter-and intra-tooth variation in the oxygen isotope composition of mammalian tooth enamel phosphate: implications for palaeoclimatological and palaeobiological research. Palaeogeogr. Palaeoclimatol. Palaeoecol. 126, 91-99.

Giscard, P.-H., Turbat, T., Crubézy, É. (Eds.), 2013. Le premier Empire des steppes en Mongolie: histoire du peuple Xiongnu et étude pluridisciplinaire de l'ensemble funéraire d'Egyin Gol. Editions Faton, Dijon, France.

Goepfert, N., Dufour, E., Gutiérrez, B., Chauchat, C., 2013. Origen geográfico de camélidos en el periodo mochica (100-800 AD) y análisis isotópico secuencial del esmalte dentario: enfoque metodológico y aportes preliminares. Bull. Inst. Fr. Détudes Andin. 25-48. https://doi.org/10.4000/bifea.869.

Gourichon, L., Parmigiani, V., 2016. Preliminary analysis of dental cementum of Lama guanicoe for the estimation of age and season at death: studies of modern specimens 
and further archaeological applications. J. Archaeol. Sci. Rep. 6, 856-861. https:// doi.org/10.1016/j.jasrep.2016.01.001.

Grant, A., 1982. The use of tooth wear as a guide to the age of domestic ungulates. In: Wilson Al, Bob (Ed.), Ageing Sexing Anim. Bones Archaeol. Sites, pp. 91-108.

Greenfield, H., Moore, N., Steppan, K., 2015. Estimating the age- and season-of-death for wild equids: a comparison of techniques utilising a sample from the late Neolithic site of bad Buchau-Dullenried, Germany. Open Quat. 1 https://doi.org/10.5334/oq. ac. Art. 3.

Greenfield, H.J., Arnold, E.R., 2008. Absolute age and tooth eruption and wear sequences in sheep and goat: determining age-at-death in zooarchaeology using a modern control sample. J. Archaeol. Sci. 35, 836-849. https://doi.org/10.1016/j. jas.2007.06.003.

Grine, F.E., 1986. Dental evidence for dietary differences in Australopithecus and Paranthropus: a quantitative analysis of permanent molar microwear. J. Hum. Evol. 15, 783-822. https://doi.org/10.1016/S0047-2484(86)80010-0.

Grue, H., Jensen, B., 1976. Annual Cementum Structures in Canine Teeth in Arctic Foxes (Alopex lagopus (L.)) from Greenland and Denmark.

Halder, J., Terzer, S., Wassenaar, L.I., Araguás-Araguás, L.J., Aggarwal, P.K., 2015. The Global Network of Isotopes in Rivers (GNIR): integration of water isotopes in watershed observation and riverine research. Hydrol. Earth Syst. Sci. 19, 3419-3431. https://doi.org/10.5194/hess-19-3419-2015.

Helmer, D., Gourichon, L., Sidi Maamar, H., Vigne, J.-D., 2005. L'élevage des caprinés néolithiques dans le sud-est de la France: saisonnalité des abattages, relations entre grottes-bergeries et sites de plein air. Anthropozoologica 40, 167-189.

Henton, E., Martin, L., Garrard, A., Jourdan, A.-L., Thirlwall, M., Boles, O., 2017. Gazelle seasonal mobility in the Jordanian steppe: the use of dental isotopes and microwear as environmental markers, applied to Epipalaeolithic Kharaneh IV. J. Archaeol. Sci. Rep. 11, 147-158. https://doi.org/10.1016/j.jasrep.2016.11.031.

Henton, E., MCorriston, J., Martin, L., Oches, E.A., 2014. Seasonal aggregation and ritual slaughter: isotopic and dental microwear evidence for cattle herder mobility in the Arabian Neolithic. J. Anthropol. Archaeol. 33, 119-131. https://doi.org/10.1016/j. jaa.2013.12.004.

Hesse, B., 1982. Slaughter patterns and domestication: the beginnings of pastoralism in western Iran. Man 17, 403-417. https://doi.org/10.2307/2801705.

Higgins, P., MacFadden, B.J., 2004. "Amount Effect" recorded in oxygen isotopes of Late Glacial horse (Equus) and bison (Bison) teeth from the Sonoran and Chihuahuan deserts, southwestern United States. Palaeogeogr. Palaeoclimatol. Palaeoecol., Incremental Growth in Vertebrate Skeletal Tissues: Paleobiol. Paleoenviron. Implications 206, 337-353. https://doi.org/10.1016/j.palaeo.2004.01.011.

Hillson, S., 2005. Teeth. Cambridge university press.

Honeychurch, W., 2010. Pastoral nomadic voices: a Mongolian archaeology for the future. World Archaeol. 42, 405-417. https://doi.org/10.1080/ 00438243.2010 .497389$.

Hoppe, K.A., Stover, S.M., Pascoe, J.R., Amundson, R., 2004. Tooth enamel biomineralization in extant horses: implications for isotopic microsampling. Palaeogeogr. Palaeoclimatol. Palaeoecol., Incremental Growth in Vertebrate Skeletal Tissues: Paleobiol. Paleoenviron. Implications 206, 355-365. https://doi.org/ 10.1016/j.palaeo.2004.01.012.

Iacumin, P., Bocherens, H., Mariotti, A., Longinelli, A., 1996. Oxygen isotope analyses of co-existing carbonate and phosphate in biogenic apatite: a way to monitor diagenetic alteration of bone phosphate? Earth Planet Sci. Lett. 142, 1-6. https://doi.org/ 10.1016/0012-821X(96)00093-3.

Jones, G.G., 2006. Tooth eruption and wear observed in live sheep from Butser Hill, the Cotswold Farm Park and five farms in the Pentland Hills, UK. In: Recent Advances in Ageing and Sexing Animal Bones. Oxbow Books, pp. 155-178.

Julien, M.-A., 2009. Chasseurs de bisons: apports de l'archéozoologie et de la biogéochimie isotopique à l'étude palethnographique et paléoéthologique du gisement épigravettien d'Amvrosievka (Ukraine). Thèse de doctorat. In: Muséum national d'Histoire naturelle, Paris (France) et Université de Montréal, Montréal (Canada).

Julien, M.-A., Rivals, F., Serangeli, J., Bocherens, H., Conard, N.J., 2015. A new approach for deciphering between single and multiple accumulation events using intra-tooth isotopic variations: application to the Middle Pleistocene bone bed of Schöningen 13 II-4. J. Hum. Evol., Special Issue: Excavations at Schöningen: New Insights into Middle Pleistocene Lifeways in Northern Europe 89, 114-128. https://doi.org/ 10.1016/j.jhevol.2015.02.012.

Knipper, C., Paulus, S., Uerpmann, M., Uerpmann, H.-P., 2008. Seasonality and land use in Bronze and Iron Age Kakhetia (Georgia). Oxygen and strontium isotope analyses on horse and cattle teeth. Archäol. Mitteilungen Aus Iran Turan 40, 149-168.

Koch, P.L., Fisher, D.C., Dettman, D., 1989. Oxygen isotope variation in the tusks of extinct proboscideans: a measure of season of death and seasonality. Geology 17, 515-519. https://doi.org/10.1130/0091-7613(1989)017<0515:OIVITT $>2$. 3.CO;2.

Koch, P.L., Tuross, N., Fogel, M.L., 1997. The effects of sample treatment and diagenesis on the isotopic integrity of carbonate in biogenic hydroxylapatite. J. Archaeol. Sci. 24, 417-429. https://doi.org/10.1006/jasc.1996.0126.

Kohn, M.J., 1996. Predicting animal $\delta^{18} \mathrm{O}$ : accounting for diet and physiological adaptation. Geochim. Cosmochim. Acta 60, 4811-4829.

Kohn, M.J., Cerling, T.E., 2002. Stable isotope compositions of biological apatite. Rev. Mineral. Geochem. 48, 455-488. https://doi.org/10.2138/rmg.2002.48.12.

Kovalev, A.A., Erdenebaatar, D., 2009. Discovery of new cultures of the bronze age in Mongolia according to the data obtained by the international central Asian archaeological expedition. Bemmann Al 149-170.

Kradin, N.N., 2011. Heterarchy and hierarchy among the ancient Mongolian nomads. Soc. Evol. Hist. 10.
Landon, D., 2014. The potential applications of tooth cement increment analysis in historical archaeology. Northeast Hist. Archaeol. 17 https://doi.org/10.22191/ neha/vol17/iss1/5.

Lee-Thorp, J.A., 2008. On isotopes and old bones. Archaeometry 50, 925-950. https:// doi.org/10.1111/j.1475-4754.2008.00441.x.

Legrand, J., 2011. Mongols et Nomades: Société, Histoire, Culture/Mongolchuud, nüüdelchin: niigem, tüüh, soyol. Textes, communications, articles (1973-2011). ADMON, Ulaanbaatar.

Lepetz, S., Decanter, F., 2013. Les restes osseux animaux du site d'Egyin Gol. In: Giscard, P.-H., Turbat, T. (Eds.), Étude du cimetière Xongniou d'Egyin Gol, p. 15.

Li, J., Zhang, S., Bunn, H.T., Sarathi, A., Gao, X., 2017. A preliminary application of dental cementum incremental analysis to determine the season-of-death of equids from the Xujiayao site, China. Sci. China Earth Sci. 60, 1183-1188. https://doi.org/ 10.1007/s11430-016-9028-x.

Longinelli, A., 1984. Oxygen isotopes in mammal bone phosphate: a new tool for paleohydrological and paleoclimatological research? Geochim. Cosmochim. Acta 48, 385-390.

Lubinski, P.M., 2001. Estimating age and season of death of pronghorn antelope (Antilocapra americana Ord) by means of tooth eruption and wear. Int. J. Osteoarchaeol. 11, 218-230. https://doi.org/10.1002/oa.536.

Luz, B., Kolodny, Y., 1985. Oxygen isotope variations in phosphate of biogenic apatites, IV. Mammal teeth and bones. Earth Planet Sci. Lett. 75, 29-36. https://doi.org/ 10.1016/0012-821X(85)90047-0.

Mainland, I., Towers, J., Ewens, V., Davis, G., Montgomery, J., Batey, C., Card, N., Downes, J., 2016. Toiling with teeth: an integrated dental analysis of sheep and cattle dentition in Iron Age and Viking-Late Norse Orkney. J. Archaeol. Sci. Rep. 6, 837-855. https://doi.org/10.1016/j.jasrep.2015.12.002.

Mainland, I.L., 1998. Dental microwear and diet in domestic sheep (Ovis aries) and goats (Capra hircus): distinguishing grazing and fodder-fed ovicaprids using a quantitative analytical approach. J. Archaeol. Sci. 25, 1259-1271. https://doi.org/10.1006/ jasc.1998.0301.

Makarewicz, C.A., Pederzani, S., 2017. Oxygen $\left(\delta^{18} \mathrm{O}\right)$ and carbon $\left(\delta^{13} \mathrm{C}\right)$ isotopic distinction in sequentially sampled tooth enamel of co-localized wild and domesticated caprines: complications to establishing seasonality and mobility in herbivores. Palaeogeogr. Palaeoclimatol. Palaeoecol. https://doi.org/10.1016/j. palaeo.2017.01.010.

Mohammat, A., Wang, X., Xu, X., Peng, L., Yang, Y., Zhang, X., Myneni, R.B., Piao, S. 2013. Drought and spring cooling induced recent decrease in vegetation growth in Inner Asia. Agric. For. Meteorol., Special Issue: Drought Inner Asia 178-179 21-30. https://doi.org/10.1016/j.agrformet.2012.09.014.

Naji, S., Colard, T., Blondiaux, J., Bertrand, B., d'Incau, E., Bocquet-Appel, J.-P., 2016. Cementochronology, to cut or not to cut? Int. J. Paleopathol. 15, 113-119. https:// doi.org/10.1016/j.ijpp.2014.05.003.

Nandintsetseg, B., Shinoda, M., 2011. Seasonal change of soil moisture in Mongolia: its climatology and modelling. Int. J. Climatol. 31, 1143-1152.

Newesely, H., 1989. Fossil bone apatite. Appl. Geochem. 4, 233-245. https://doi.org/ 10.1016/0883-2927(89)90023-1.

Noddle, B., 1974. Ages of epiphyseal closure in feral and domestic goats and ages of dental eruption. J. Archaeol. Sci. 1, 195-204. https://doi.org/10.1016/0305-4403 (74)90042-9.

Nývltová Fišáková, M., 2013. Seasonality of Gravettian sites in the middle Danube region and adjoining areas of central Europe. Quat. Int. 294, 120-134. https://doi.org/ 10.1016/j.quaint.2011.08.017.

Passey, B.H., Cerling, T.E., 2002. Tooth enamel mineralization in ungulates: implications for recovering a primary isotopic time-series. Geochim. Cosmochim. Acta 66, 3225-3234. https://doi.org/10.1016/S0016-7037(02)00933-X.

Payne, S., 1973. Kill-off patterns in sheep and goats: the mandibles from Aşvan Kale. Anatol. Stud. 23, 281-303. https://doi.org/10.2307/3642547.

Pederzani, S., Britton, K., 2019. Oxygen isotopes in bioarchaeology: principles and applications, challenges and opportunities. Earth Sci. Rev. 188, 77-107. https://doi. org/10.1016/j.earscirev.2018.11.005.

Piao, S., Mohammat, A., Fang, J., Cai, Q., Feng, J., 2006. NDVI-based increase in growth of temperate grasslands and its responses to climate changes in China. Global Environ. Change 16, 340-348. https://doi.org/10.1016/j.gloenvcha.2006.02.002.

Pike-Tay, A., 1995. Variability and synchrony of seasonal indicators in dental cementum microstructure of the Kaminiriak Caribou population. ARCHAEOFAUNA 273-284, 0.

Rivals, F., Deniaux, B., 2005. Investigation of human hunting seasonality through dental microwear analysis of two Caprinae in late Pleistocene localities in Southern France. J. Archaeol. Sci. 32, 1603-1612. https://doi.org/10.1016/j.jas.2005.04.014.

Rivals, F., Prignano, L., Semprebon, G.M., Lozano, S., 2015. A tool for determining duration of mortality events in archaeological assemblages using extant ungulate microwear. Sci. Rep. 5, 17330. https://doi.org/10.1038/srep17330.

Rivals, F., Schulz, E., Kaiser, T.M., 2009. A new application of dental wear analyses: estimation of duration of hominid occupations in archaeological localities. J. Hum. Evol. 56, 329-339. https://doi.org/10.1016/j.jhevol.2008.11.005.

Rodríguez-Hidalgo, A., Rivals, F., Saladié, P., Carbonell, E., 2016. Season of bison mortality in TD10.2 bone bed at Gran Dolina site (Atapuerca): integrating tooth eruption, wear, and microwear methods. J. Archaeol. Sci. Rep. 6, 780-789. https:// doi.org/10.1016/j.jasrep.2015.11.033.

Rozanski, K., Araguás-Araguás, L., Gonfiantini, R., 1993. Isotopic patterns in modern global precipitation. Clim. Change Cont. Isot. Rec. 78, 1-36. https://doi.org/ 10.1029/GM078p0001.

Schmaus, T.M., Doumani Dupuy, P.N., Frachetti, M.D., 2019. Variability in seasonal mobility patterns in Bronze and Iron Age Kazakhstan through cementum analysis. Quat. Int. https://doi.org/10.1016/j.quaint.2019.04.018. 
Silver, I.A., 1963. The ageing of domestic animals. Sci. Archaeol. Compr. Surv. Prog. Res. 250.

Smith, T.M., Tafforeau, P., 2008. New visions of dental tissue research: tooth development, chemistry, and structure. Evol. Anthropol. Issues News Rev. 17, 213-226. https://doi.org/10.1002/evan.20176.

Solounias, N., Semprebon, G., 2002. Advances in the reconstruction of ungulate ecomorphology with application to early fossil equids. Am. Mus. Novit. 225, 1-49. https://doi.org/10.1206/0003-0082(2002)366<0001:AITROU>2.0.CO;2.

Straight, W.H., Barrick, R.E., Eberth, D.A., 2004. Reflections of surface water, seasonality and climate in stable oxygen isotopes from tyrannosaurid tooth enamel. Palaeogeogr. Palaeoclimatol. Palaeoecol., Incremental Growth in Vertebrate Skeletal Tissues: Paleobiol. Paleoenviron. Implications 206, 239-256. https://doi.org/ 10.1016/j.palaeo.2004.01.006.

Stuart-Williams, H.L.Q., Schwarcz, H.P., 1997. Oxygen isotopic determination of climatic variation using phosphate from beaver bone, tooth enamel, and dentine. Geochim. Cosmochim. Acta 61, 2539-2550. https://doi.org/10.1016/S0016-7037(97)001129.

Stutz, A.J., 2002. Polarizing microscopy identification of chemical diagenesis in archaeological cementum. J. Archaeol. Sci. 29, 1327-1347. https://doi.org/ 10.1006/jasc. 2001.0805.

Suga, S., 1982. Progressive mineralization pattern of developing enamel during the maturation stage. J. Dent. Res. Spec No 1532-1542.

Taylor, W.T.T., 2017. Horse demography and use in bronze age Mongolia. Quat. Int. 436, 270-282. https://doi.org/10.1016/j.quaint.2015.09.085.

Teaford, M.F., 2007. What do we know and not know about dental microwear and diet. In: Evolution of the Human Diet: the Known, the Unknown and the Unknowable. Oxford University Press, pp. 106-132.

Trautz, O.R., 1967. Crystalline organization of dental mineral. In: Structural and Chemical Organization of Teeth. Elsevier, pp. 165-200.

Upex, B., Dobney, K., 2012. Dental enamel hypoplasia as indicators of seasonal environmental and physiological impacts in modern sheep populations: a model for interpreting the zooarchaeological record. J. Zool. 287, 259-268.

van Dam, J.A., Reichart, G.J., 2009. Oxygen and carbon isotope signatures in late Neogene horse teeth from Spain and application as temperature and seasonality proxies. Palaeogeogr. Palaeoclimatol. Palaeoecol. 274, 64-81. https://doi.org/ 10.1016/j.palaeo.2008.12.022.

Weinreb, M.M., Sharav, Y., 1964. Tooth development in sheep. Am. J. Vet. Res. 25, 891-908.

West, A.G., February, E.C., Bowen, G.J., 2014. Spatial analysis of hydrogen and oxygen stable isotopes ("isoscapes") in ground water and tap water across South Africa. J. Geochem. Explor. 145, 213-222. https://doi.org/10.1016/j.gexplo.2014.06.009.

Wright, J., Honeychurch, W., Amartuvshin, C., 2009. The xiongnu settlements of Egiin Gol, Mongolia. Antiquity 83, 372-387. https://doi.org/10.1017/ S0003598X00098495.

Wright, J., Makarewicz, C., 2015. Perceptions of pasture: the role of skill and networks in maintaining stable pastoral nomadic systems in Inner Asia. In: Kerner, S., Dann, R., Jensen, P.B. (Eds.), Climate and Ancient Societies, pp. 267-288. Copenhagen.

Zazzo, A., Balasse, M., Passey, B.H., Moloney, A.P., Monahan, F.J., Schmidt, O., 2010. The isotope record of short- and long-term dietary changes in sheep tooth enamel: implications for quantitative reconstruction of paleodiets. Geochim. Cosmochim. Acta 74, 3571-3586. https://doi.org/10.1016/j.gca.2010.03.017.

Zazzo, A., Balasse, M., Patterson, W.P., 2005. High-resolution $\delta^{13} \mathrm{C}$ intratooth profiles in bovine enamel: implications for mineralization pattern and isotopic attenuation. Geochim. Cosmochim. Acta 69, 3631-3642. https://doi.org/10.1016/j. gca.2005.02.031.

Zazzo, A., Bendrey, R., Vella, D., Moloney, A.P., Monahan, F.J., Schmidt, O., 2012. A refined sampling strategy for intra-tooth stable isotope analysis of mammalian enamel. Geochim. Cosmochim. Acta 84, 1-13. https://doi.org/10.1016/j. gca.2012.01.012.

Zazzo, A., Lécuyer, C., Mariotti, A., 2004. Experimentally-controlled carbon and oxygen isotope exchange between bioapatites and water under inorganic and microbiallymediated conditions. Geochim. Cosmochim. Acta 68, 1-12. https://doi.org/ 10.1016/S0016-7037(03)00278-3.

Zazzo, A., Lepetz, S., Magail, J., Gantulga, J.-O., 2019. High-precision dating of ceremonial activity around a large ritual complex in Late Bronze Age Mongolia. Antiquity 93, 80-98. https://doi.org/10.15184/aqy.2018.175.

Zeder, M.A., 2006. Reconciling rates of long bone fusion and tooth eruption and wear in sheep (Ovis) and goat (Capra). In: Recent Advances in Ageing and Sexing Animal Bones, pp. 87-118. 